\title{
THE IMPACT OF THE MELTING AND POURING PROCESS ON THE QUALITY OF THE BIGGEST ROCKING BELL CALLED VOX PATRIS
}

doi: 10.2478/cqpi-2019-0031

Date of submission of the article to the Editor: 22/03/2019

Date of acceptance of the article by the Editor: 14/05/2019

Dariusz Bartocha1 - orcid id: 0000-0002-3011-4434

Czesław Baron ${ }^{1}$ - orcid id: 0000-0001-7205-5797

${ }^{1}$ Silesian University of Technology, Poland

\begin{abstract}
The paper describes the process of melting, metalworking and pouring the form of the world's largest 55-ton rocking bell called Vox Patris. The project was carried out by Pracownia Ludwisarska of Jan Felczyński from Przemyśl in cooperation with Rduch Bells \& Clocks from Czernica and Metalodlew SA from Kraków. Comprehensive scientific and technical support of the project was provided by the Department of Foundry of the Silesian University of Technology. The bell is made of bronze, which is an alloy of copper and tin with a content of tin at the level of $20 \%$. The foundry, where the melting and pouring process took place, had two 14 ton electric furnaces, 15 ton transport pouring ladle and a 60 ton collection ladle. Therefore, it was necessary to determine the minimum temperature of the pouring and the conditions for holding the liquid metal so that the metal from the first cast would not solidify before accumulating its total amount (four melts) (Bartocha and Baron, 2015; Bartocha and Baron, 2016). The study presents the tests of alloy properties and a series of computer simulations. Thanks to them the maximum and minimum permissible temperature of metal overheating has been determined (Bartocha, 2017). The final stage of the cast was the mold pouring process. The filling system was responsible for the correct performance of this process. This system comprised a tank (collector) under a doublestopper 60-ton main ladle, an elevenmeter tapping spout, an infusion tank and a downgate. The task of the gating system is uniform and continuous supply of liquid metal to the mold until it is completely filled. The unusual layout, that was used, required checking many factors. Various configurations of the system parameters have been tested based on the series of computer simulations (Czochlarski and Bukowski, 1935; Ignaszak, 1999).
\end{abstract}

Keywords: bell, pouring, Vox Patris

\section{PRELIMINARY RESEARCH}

The main factors in the metal preparation process are both strictly defined chemical composition and the melting and overheating temperature of the alloy. In the process 
of cooling and solidification, an important role is played by gas dissolved in the metal, which causes forming of axial or gaseous microporosity. It results in the lack of proper bell sound. To avoid this, the metal must be overheated and kept at such temperature to allow the gas to dissolve and then, by carrying out final degassing, control the amount of gas remaining in the metal bath. Overheating of the metal can't be too big because alloy components are intensively oxidized causing a significant deterioration of its quality after exceeding the critical temperature. What's more, the appropriate amount and the type of materials deoxidizing the bath and protecting and isolating the liquid metal mirror were determinated and selected for the process.

Due to the fact that Metalodlew had two induction furnaces with a capacity of 14 tons, it was necessary to carry out four melts and collect the metal in a collecting ladle. For this purpose, a 60-ton bottom-pouring ladle was used.

It was necessary to determine the order of melting and holding metal. For this purpose, laboratory tests were carried out. Thanks to them, the critical temperature was determined, above which the alloy components intensively oxidize causing a significant deterioration of its quality. Based on the thermophysical properties of the alloy and the computer simulation cycle, the maximum and minimum permissible temperature for the overheating of both the transport ladles and the bottom-pouring ladle has been determined. The results from simulation tests showing the temperature drop in a transport ladle with an insulated mirror and without insulation are shown in Fig. 1a-e and Fig. 2 a-e.

a)

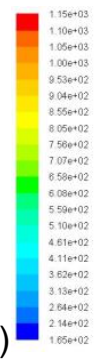

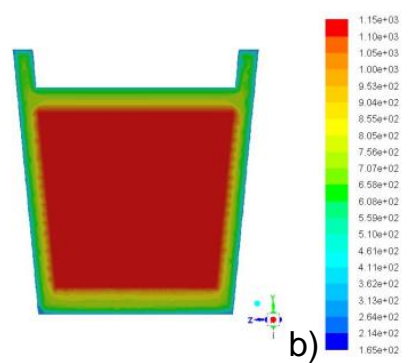

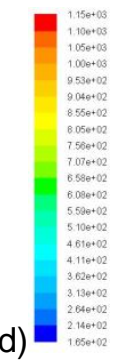

b)

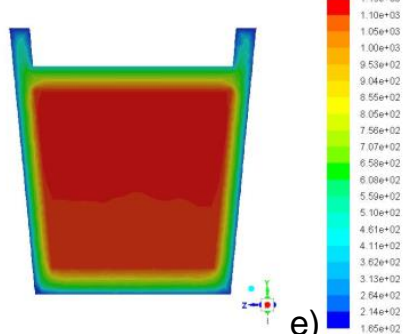

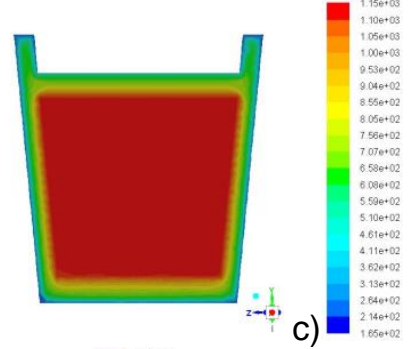

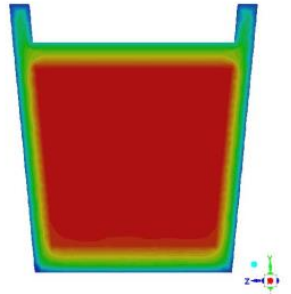

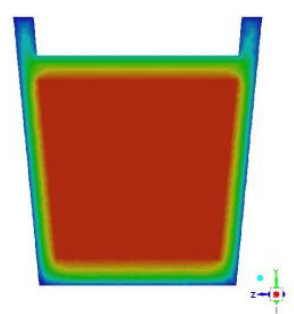

Fig. 1 The temperature drop in the transporting ladle with the use of exothermic powder:

a) $0,5 \mathrm{~h}, \mathrm{~b}) 1 \mathrm{~h}, \mathrm{c}) 1,5 \mathrm{~h}, \mathrm{~d}) 2 \mathrm{~h}, \mathrm{e}) 2,5 \mathrm{~h}$

a)

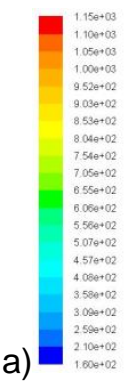

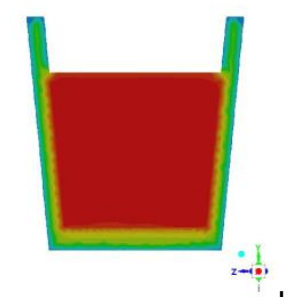

b)

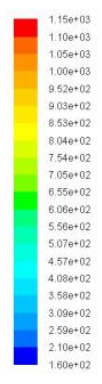

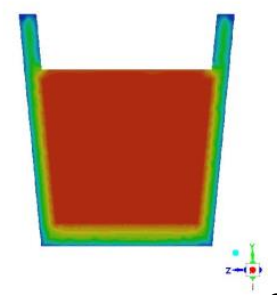

c)

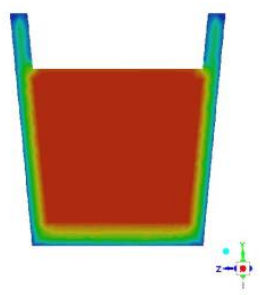


d)

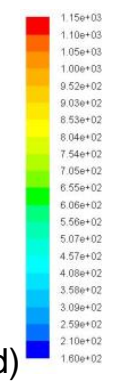

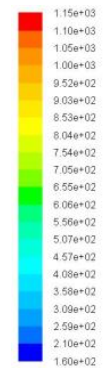

e)

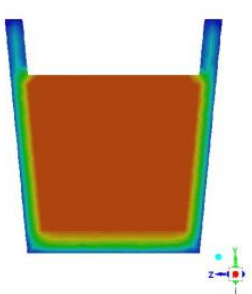

Fig. 2. The temperature drop in a transport ladle without an exothermic powder: a) $0,5 \mathrm{~h}, \mathrm{~b}) \mathrm{h}$, c) $1,5 \mathrm{~h}, \mathrm{~d}) 2 \mathrm{~h}, \mathrm{e}) 2,5 \mathrm{~h}$

The same simulation cycle was carried out for a bottom-pouring collecting ladle. The results of the $B 20$ bronze temperature drop $\left(T_{L}=890^{\circ} \mathrm{C}, T_{S}=798^{\circ} \mathrm{C}\right)$ in the ladle (no caps included) are calculated after 15 minutes in depend on the amount of metal (14t and 28t) and the application or not of exothermic powder backfilling. The results are shown in Fig. 3-6 a,b.

The initial conditions for all calculation options were the same:

- Metal temperature $1100^{\circ} \mathrm{C}$,

- The temperature of the lining of the ladle $650^{\circ} \mathrm{C}$,

- Shell ladle temperature $100^{\circ} \mathrm{C}$,

- Temperature of the insulation layer $650^{\circ} \mathrm{C}$, thickness of the exothermic powder backfilling layer $40 \mathrm{~mm}$,

- Air temperature in the ladle $100^{\circ} \mathrm{C}$,

- Ambient temperature $20^{\circ} \mathrm{C}$.

a)

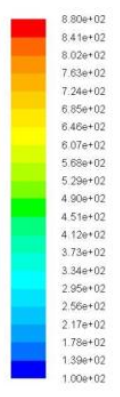

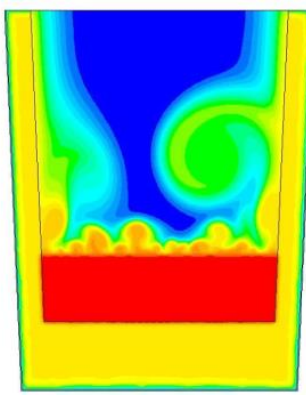

b)
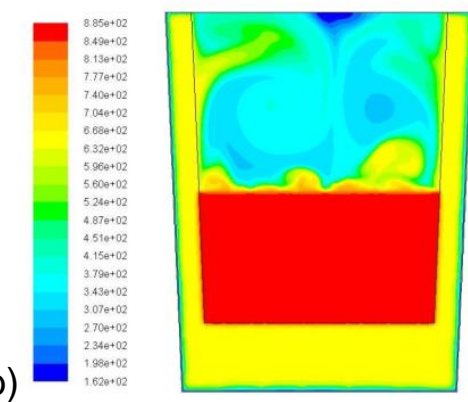

Fig. 3. The temperature distribution in a ladle after 15 minutes without exothermic powder backfilling; a) 14t, b) $28 \mathrm{t}$

a)
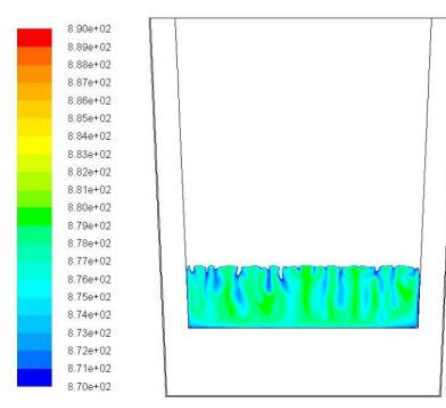

b)
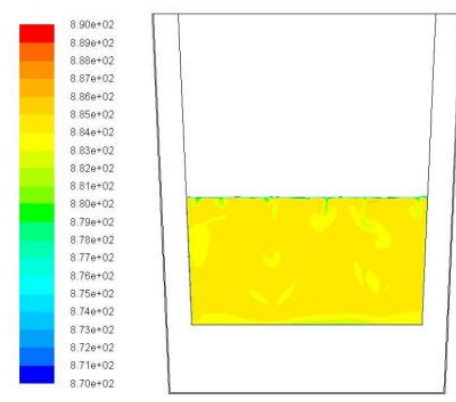

Fig. 4. The comparison of the temperature distribution in the ladle after 15 minutes without exothermic powder backfilling (using the same color scale); a) 14t, b) $28 \mathrm{t}$ 
a)

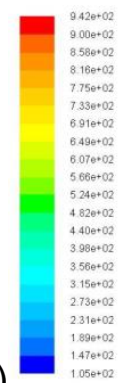

Fig. 5. The temperature distribution in a ladle after 15 minutes with exothermic powder backfilling; a) 14t, b) $28 \mathrm{t}$ a)
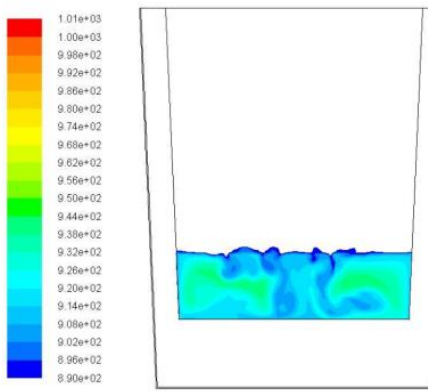

b)
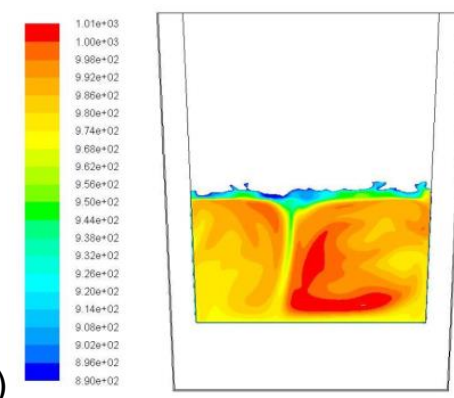

Fig. 6. The comparison of the temperature distribution in the ladle after 15 minutes with exothermic powder backfilling (using the same color scale); a) 14t, b) $28 \mathrm{t}$

The results of the temperature drop depending on the assumed collective conditions are provided in the Table 1 and Figure 7.

Table 1

The temperature drop depending on the conditions

\begin{tabular}{|c|c|c|c|c|c|c|}
\hline \multirow[t]{2}{*}{ Program } & \multirow{2}{*}{$\begin{array}{c}\text { Type of } \\
\text { ladle }\end{array}$} & \multirow[t]{2}{*}{ Time $h$} & \multicolumn{2}{|c|}{ insulated mirror } & \multicolumn{2}{|c|}{ uninsulated mirror } \\
\hline & & & $\min$ & $\max$ & $\min$ & $\max$ \\
\hline \multirow{15}{*}{$\begin{array}{l}\text { Ansys } \\
\text { Fluent }\end{array}$} & \multirow{5}{*}{$\begin{array}{l}60 t \\
\text { Tp } 700 \\
30 t \\
\text { Tp } 1100\end{array}$} & 0,5 & 1045 & 1086 & 795 & 1079 \\
\hline & & 1 & 1044 & 1075 & 781 & 1061 \\
\hline & & 1,5 & 1042 & 1066 & 762 & 1045 \\
\hline & & 2 & 1038 & 1059 & 754 & 1031 \\
\hline & & 2,5 & 1033 & 1052 & 743 & 1017 \\
\hline & \multirow{5}{*}{$\begin{array}{l}15 t \\
\text { Tp } 800 \\
15 t \\
\text { Tp } 1150\end{array}$} & 0,5 & 1096 & 1136 & 786 & 1126 \\
\hline & & 1 & 1094 & 1124 & 757 & 1100 \\
\hline & & 1,5 & 1088 & 1115 & 752 & 1084 \\
\hline & & 2 & 1084 & 1108 & 718 & 1062 \\
\hline & & 2,5 & 1077 & 1100 & 722 & 1048 \\
\hline & \multirow{5}{*}{$\begin{array}{l}15 t \\
T p 700 \\
15 t \\
T p 1150\end{array}$} & 0,5 & 1084 & 1131 & & \\
\hline & & 1 & 1080 & 1116 & & \\
\hline & & 1,5 & 1072 & 1105 & & \\
\hline & & 2 & 1066 & 1096 & & \\
\hline & & 2,5 & 1059 & 1087 & & \\
\hline
\end{tabular}




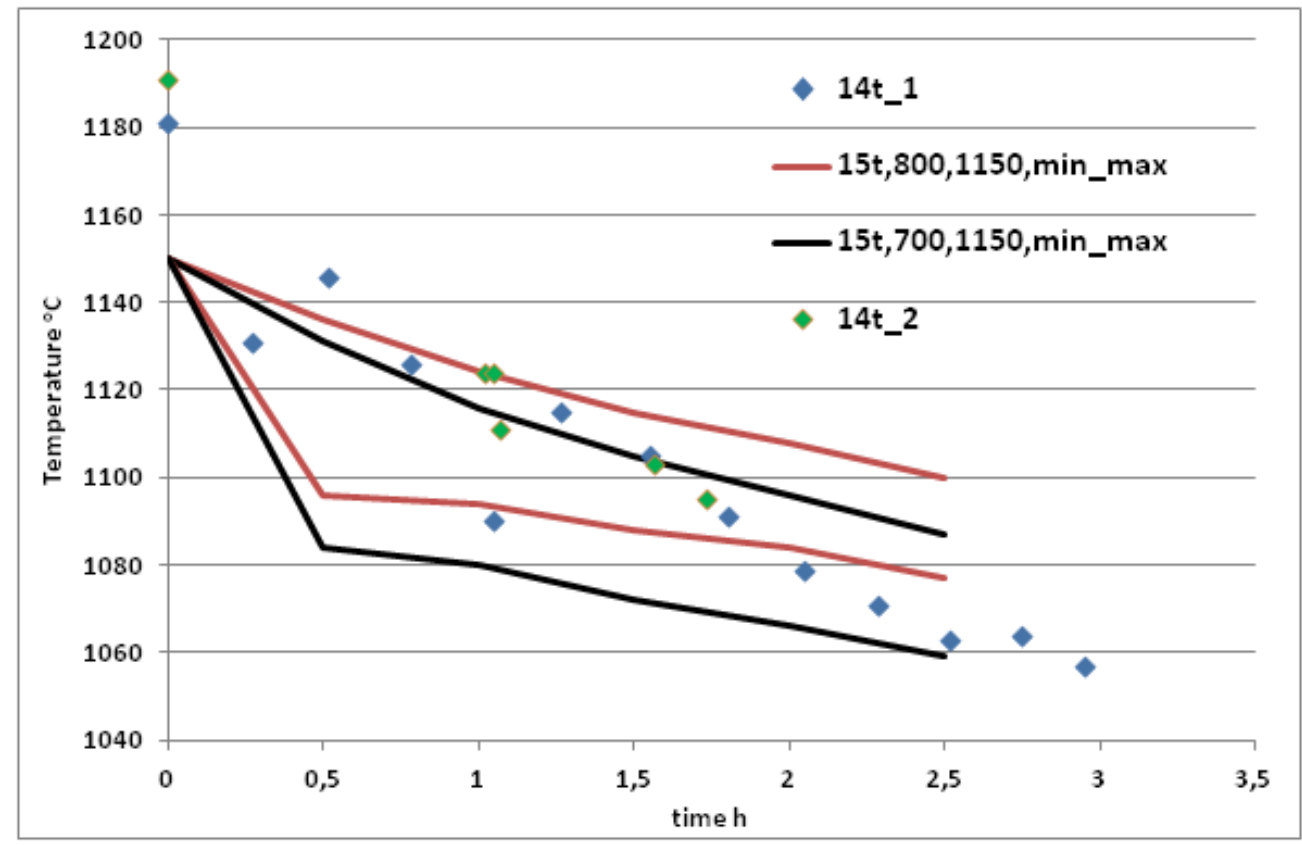

Fig. 7. Plan of melting

\section{MELTING PROCESS}

As the Otto Junker furnace works in tandem, it was possible to melt only in one 14-ton melting-pot with full power. At that time, a metal charge was loaded into the second melting-pot. After completion of the melting, the temperature in the first melting-pot was set to keep the liquid state, and the melting of the metal in the second melting-pot was started. When the metal reached the appropriate superheat temperature $\left(1200^{\circ} \mathrm{C}\right)$, it was poured into the transport ladles. It was kept in these ladles until the next two portions were melted. To reduce heat loss, the ladles were heated to the temperature of $800^{\circ} \mathrm{C}$. An exothermic powder was used to insulate liquid metal mirror and the lid covering the ladle (Ignaszak and Popielarski, 2003).

In the first ladle the temperature recorded after the trigger was $1181^{\circ} \mathrm{C}$, and after 3 hours of holding it was $1057^{\circ} \mathrm{C}$. Thus, a decrease of $124^{\circ} \mathrm{C}$ was recorded. In the second ladle, the initial temperature was $1208^{\circ} \mathrm{C}$, and after 1 and 50 minutes $1095^{\circ} \mathrm{C}$, so the temperature drop was $113^{\circ} \mathrm{C}$. After melting the second portion, when the metal reached the temperature of $1200^{\circ} \mathrm{C}$, the process of pouring the metal to the main ladle was started. In order to deoxygenate the liquid metal, phosphor copper was placed at the bottom of the transport ladle. At the beginning, a metal keeping in the ladle was poured and then metal from the furnace. It took 30 minutes to transport the ladle and to pour the metal into the bottom-pouring collecting ladle. The temperature of the metal in the bottom-pouring ladle before the mold pouring process was $1080^{\circ} \mathrm{C}$. Schematic of the melting plan is presented in Fig. 8 


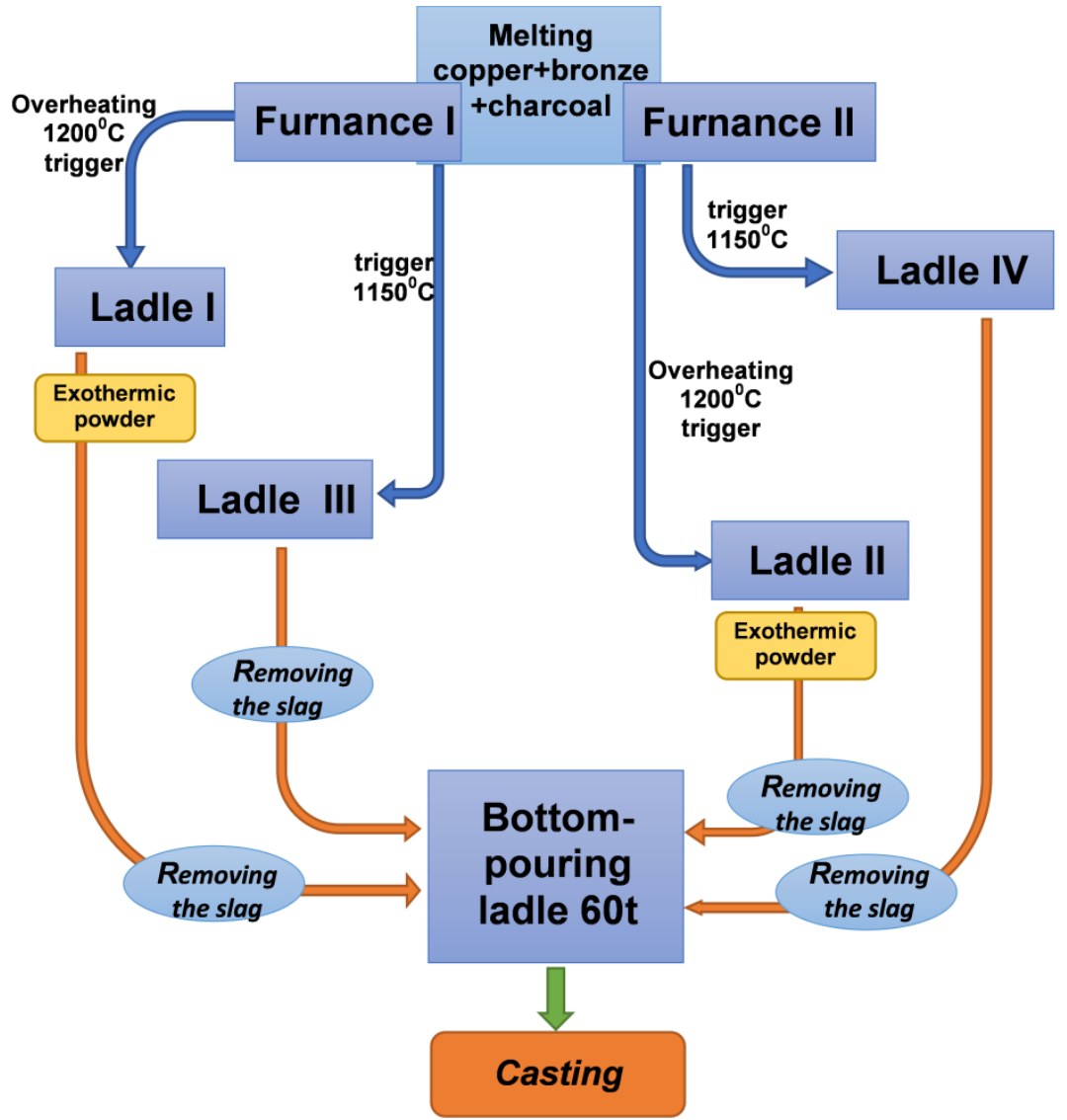

Fig. 8. Plan of melting

\section{GATING SYSTEM}

Another important task was to design the gating system. This system consists of a tank (collector) under the bottom-pouring collecting ladle (Fig.9), an eleven-meter tapping spout, an pouring basin and a downgate shown in the Figure 10.
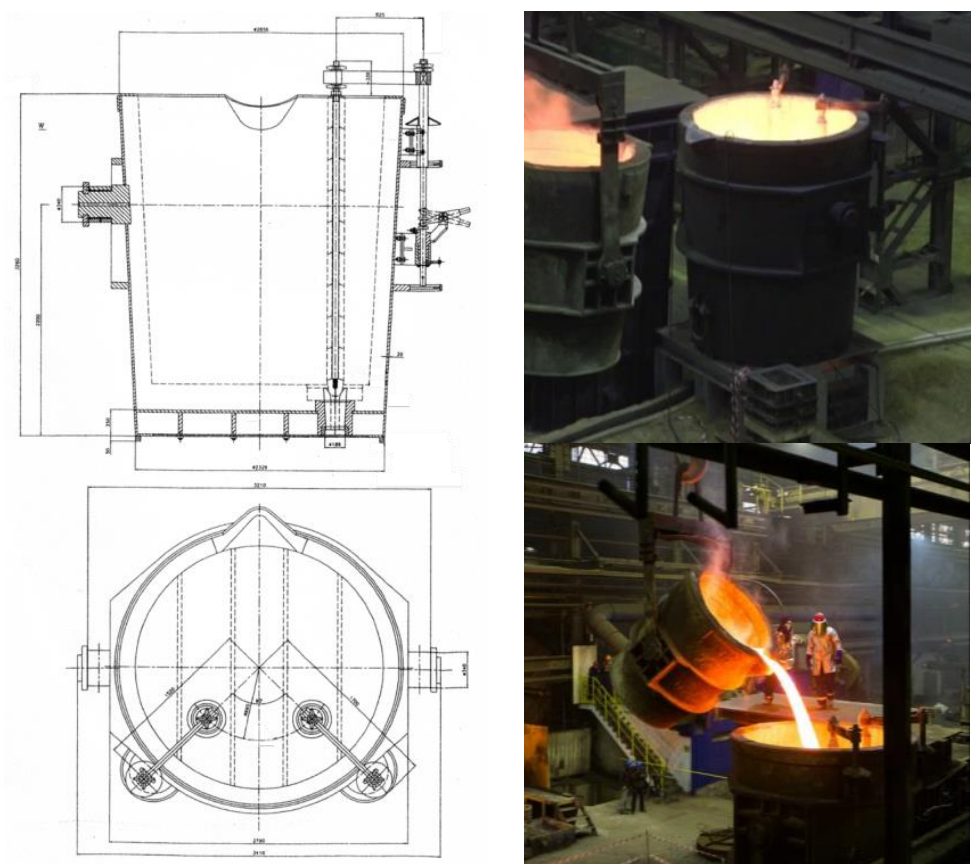

Fig. 9. Scheme and photos of a bottom-pouring collecting ladle 


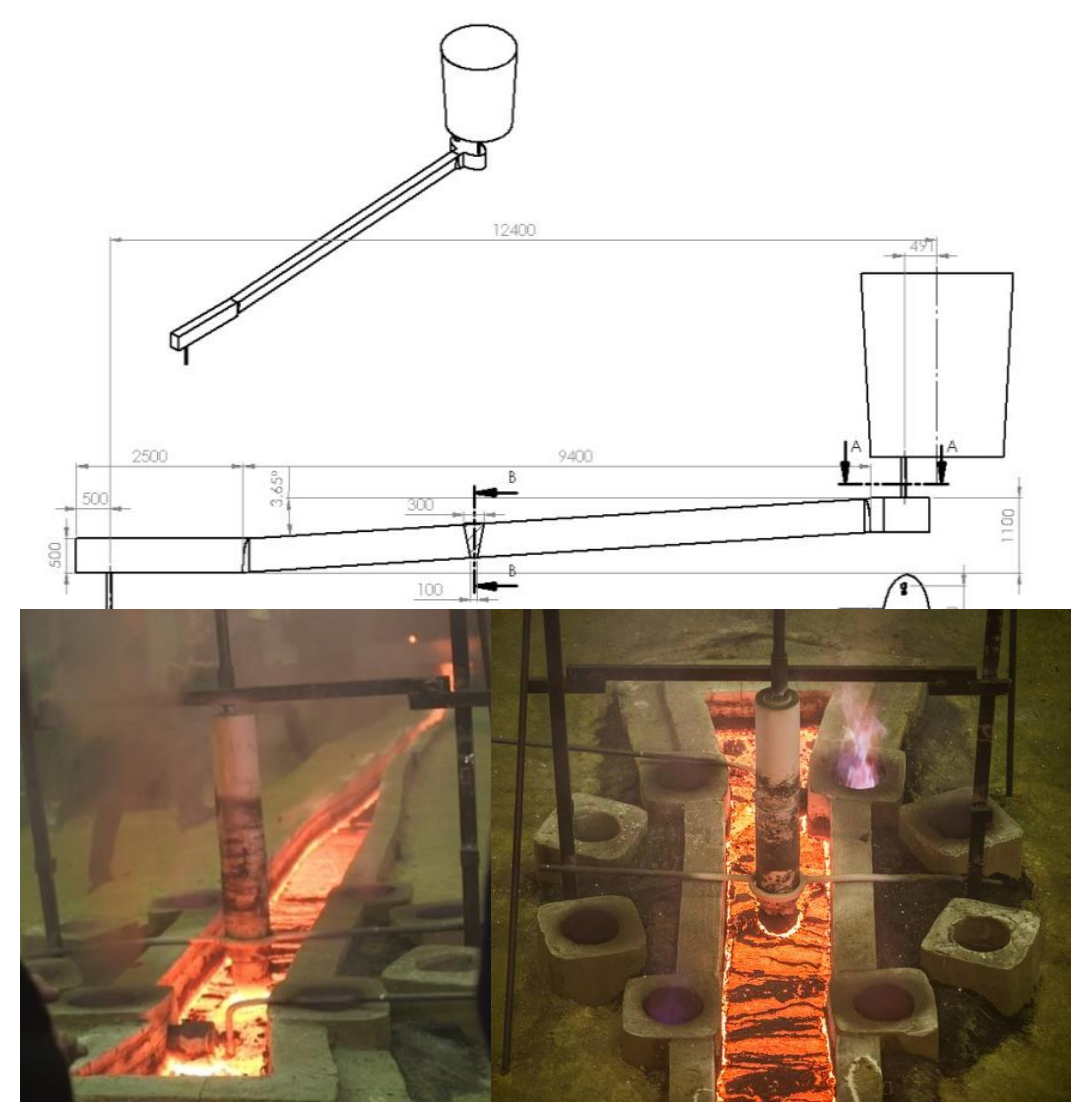

Fig. 10. Scheme and photos of a tapping spout, an pouring basin and a downgate

The task of the gating system was uniform and continuous supply of liquid metal to the mold until it was completely filled. In the case of such a non-standard both dimensionally and structurally layout, the basic parameters, which one should determine, were: the diameters of the pouring holes in the main bottom-pouring collecting ladle, the angle of the gutter from the collector under the ladle to the pouring basin, the volume of the tank itself and the diameter of the downgate. Based on a series of computer simulations, various configurations of the system parameters have been tested. According to the final version of the system that meets the requirements of the pouring process, it took about 10 minutes to conduct the pouring process. Schematically, the main stages of pouring are shown in the Figure 11 a-d.

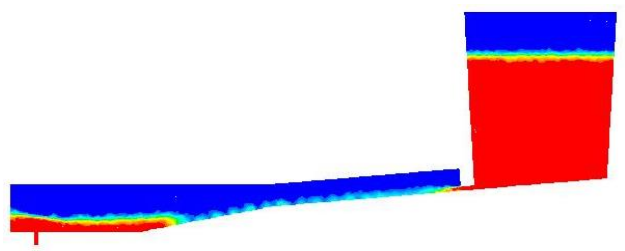

a) The beginning of pouring. Opening the first bottom-pour stopper

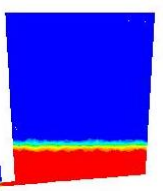

c) Opening the second bottom-pour stopper

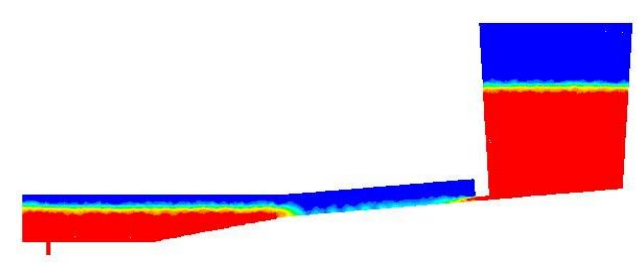

b) Opening ladle stopper in downgate

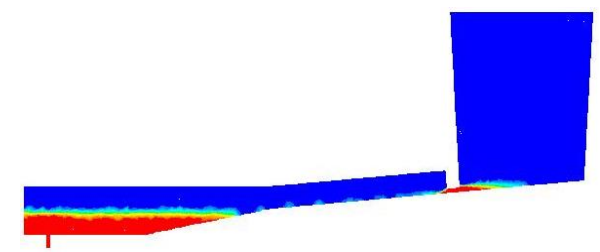

d) And of pouring

Fig. 11. Stages of mould pouring 


\section{DOWNGATE}

The last element having a direct impact on the process of pouring was the downgate. Due to the flow velocity and long potting time, it had to be designed in a construction and material way to ensure a constant and even flow of metal to the mold. It was important to avoid the air getting inside during the pouring of the bell. Hence, such a high level of metal in the tapping spout and the gating system was maintained. Metal flow regulation was possible both in the bottom-pouring ladle (two ladle stopper) and in the downgate (one ladle stopper). Due to the fact that the gating system had to withstand the rapid flow of high temperature metal, it was decided to make it of refractory ceramics, which consisted of 7 scratch elements (Fig. 12) instead of the traditional clay-based mass. Special feet supporting the downgate allowed uniform and even distribution of the metal in the mold.

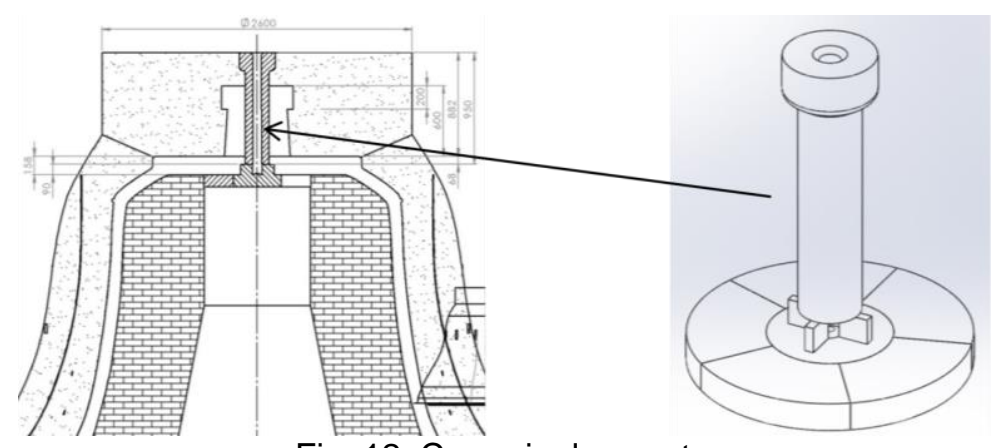

Fig. 12. Ceramic downgate

\section{SUMMARY}

The carried out preliminary tests, the design of the gating system with the downgate and the determination of the parameters related to the entire melting process enabled the preparation of metal with the appropriate temperature and chemical composition. In spite of the troubles connected with melting and keeping metal the puring temperature for such alloy was maintained. Thanks to this, the priming process was conducted without any problems. The total flooding time was 10 minutes. The obtaining the cast without both surface faults (minimal chasing process) and inner faults (unitary microstructure) was the effect of conducted researches.

\section{REFERENCES}

Bartocha, D., Baron, C., 2015. „The Secret” of Traditional Technology of Casting Bells. Archives of Foundry Engineering, 15, 3.

Bartocha, D., Baron, C., 2016. Influence of Tin Bronze Melting and Pouring Parameters on Its Properties and Bells' Tone. Archives of Foundry Engineering, 16, 4.

Bartocha, D., 2017. Rola wrażliwości na grubość ścianki brązu cynowego w predykcji częstotliwości drgań własnych dzwonów. Archives of Foundry Engineering.

Czochlarski, J., Bukowski, Z., 1935. Deoxidation of brasses and bronzes. Wiadomości Instytutu Metalurgii, Warszawa.

Ignaszak, Z., Popielarski, P., 2003. Właściwości termofizyczne otulin izolacyjno egzotermicznych oznaczone metodą zagadnień odwrotnych. Archives of Foundry Engineering, 3(9), 207-220.

Ignaszak, Z., 1999. Simulation model sensitivity to quality of material properties. Solidification of Metals and Alloys, 1(40), 25-36 